\title{
InGaAs 晶体固-液相变过程中的拓扑结构的演变机制
}

\author{
何帆, 张晋敏*, 高廷红, 田泽安, 梁永超, 郭笑天, 卢顺顺, 陈庆, 谢泉 \\ 贵州大学大数据与信息工程学院, 新型光电子材料与技术研究所, 贵阳 550025 \\ * 联系人, E-mail: jmzhang@gzu.edu.cn
}

2016-08-04 收稿, 2016-10-17 修回, 2016-10-17 接受, 2017-02-07 网络版发表 国家自然科学基金(61264004)、贵州省国际科技合作项目(黔科合外 $\mathrm{G}$ 字[2012]7004)、贵州省高层次创新人才培养项目(黔科合人才[2015] 4015)、贵州省自然科学基金(黔科合 J 字[2013]2119)、贵州省优秀教育科技人才省长基金(黔省专合字[2011]40 号)和贵州大学研究生创新 基金(研理工 2016067)资助

\begin{abstract}
摘要采用分子动力学模拟InGaAs晶体固-液相变过程, 并运用径向分布函数、键角分布函数、配位数统计及可 视化等方法，从微观结构的不同层面分析了固-液相变过程的结构演变.结果表明：对于InGaAs体系，固-液相变 过程中的微观结构发生了很大的变化，在一级相变时，其原子平均能量和比体积、径向分布函数、键角分布函数、 配位数和原子截面图、局部原子分布以及钻石结构分析都显示出很明显的变化. 熔化过程中InGaAs晶体原子间共 价键发生断裂, 体系从四配位结构变成三配位结构, 通过占主导作用的三配位结构, 结合少量的四配位结构, 形 成三配位结构之间的互连接和三配位结构穿插四配位结构的连接形成的拓扑无序的液态结构.
\end{abstract}

关键词分子动力学模拟, InGaAs 晶体, 固-液相变, 拓扑结构

熔化是指由固态到液态的相转变, 是自然界中 常见的物理现象, 也是金属和半导体等材料在加工 过程中需要经历的一个相变过程, 与材料的制备和 性能密切相关. 目前, 主要的熔化判据有两种, 分别 是Lindemann热振幅判据 ${ }^{[1]}$ 和 Born刚性失稳判据 ${ }^{[2]}$. 2001年, Jin等人 ${ }^{[3]}$ 通过分子动力学模拟, 从原子层次 上找到了两种判据的内在联系, 实现了Lindemann判 据和Born判据的统一. 在实验上难以对熔化过程进 行微观结构的跟踪研究, 而采用计算机模拟可以得 到熔化过程的大量微观结构信息, 能很好地解释熔 化过程中晶体的有序排列是如何变为无规的液相结 构. 近年来, 许多研究者运用分子动力学模拟研究了

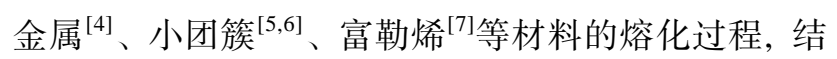
合计算机可视化技术, 很好地展现了熔化过程中微 观结构的演变情况.

三元半导体合金 $\mathrm{In}_{x} \mathrm{Ga}_{1-x} \mathrm{As}$, 可通过调节其组分
在大范围内调节材料的电学参数、光学带隙等, 使得 其在微电子和光电子器件上具有重要的应用价值, 因而对于三元半导体合金结构的研究越来越受到重 视 ${ }^{[8,9]}$. 在实验上, Suzuki等人 ${ }^{[10]}$ 研究了多组分区域熔 化三元半导体InGaAs块状晶体的生长. 在理论模拟 上, Titantah等人 ${ }^{[1]}$ 利用Tersoff势研究了 $\operatorname{In}_{x} \mathrm{Ga}_{1-x} \mathrm{As}$ 晶 体键长的变化, 通过优化 Tersoff势的参数更加精确 地描述了 In-Ga和In-As的键长; Adhikari等人 ${ }^{[12]}$ 用分 子动力学模拟比较了价力场和 Tersoff势场对 $\operatorname{In}_{x} \mathrm{Ga}_{1-x}$ As 合金结构性能的影响, 研究得到Tersoff势可以更 加准确地预测温度对合金微观结构的影响. 材料的 宏观特性主要是由其微观结构决定的, 但目前大多 数有关熔化过程的研究都是基于动力学方面的, 而 缺乏对熔化过程中微观结构演变机制的研究, 因而 研究InGaAs晶体熔化过程中微观结构的演变对开发 新型光电子材料和器件具有重大研究意义.

引用格式: 何帆, 张晋敏, 高廷红, 等. InGaAs 晶体固-液相变过程中的拓扑结构的演变机制. 科学通报, 2017, 62: 693-699 He F, Zhang J M, Gao T H, et al. Evolution mechanism of the topological structure during solid-liquid phase transition of InGaAs crystal (in Chinese). Chin Sci Bull, 2017, 62: 693-699, doi: 10.1360/N972016-00742 
在熔化过程中, 采用周期性边界条件模拟没有 表面、界面、位错和缺陷等理想晶体, 研究发现, 晶 体的熔化是来自体系内部的自发成核 ${ }^{[13]}$, 但对固-液 相变过程中的动力学行为和微观结构演变规律仍旧 扑朔迷离. 本文拟运用分子动力学方法, 采用已被证 实适用于模拟结构相对复杂的 $\mathrm{In}_{x} \mathrm{Ga}_{1-x} \mathrm{As}$ 共价键系统 的 Tersoff势函数 ${ }^{[14,15]}$, 对理想InGaAs 晶体的熔化过

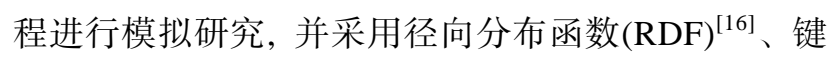
角分布函数 $(\mathrm{ADF})^{[17,18]}$ 及可视化等方法, 挖掘理想 InGaAs 晶体熔化过程的微观结构演变规律, 探究其 固-液相变机制.

\section{1 模拟计算条件和方法}

\section{1 势函数}

势函数是分子动力学模拟的基础, 其准确性直接 影响到计算结果的正确性. 本文采用由Tersoff ${ }^{[14,15]} 1986$ 年提出的Tersoff势函数来模拟理想 $\mathrm{InGaAs}$ 晶体的熔 化过程. 该势不仅考虑了共价键及原子局部环境、键 角等因素对键级的影响, 并能正确模拟共价键的形 成与破坏. 近年来已有许多研究者采用Tersoff势, 运 用分子动力学对熔化过程进行模拟计算 ${ }^{[19,20]}$. Tersoff 势函数模型如下:

$$
\begin{gathered}
E=\sum_{i} E_{i}=\frac{1}{2} \sum_{i \neq j} V_{i j}, \\
V_{i j}=f_{c}\left(r_{i j}\right)\left[f_{R}\left(r_{i j}\right)+b_{i j} f_{A}\left(r_{i j}\right)\right],
\end{gathered}
$$

其中, $f_{R}$ 为排斥势, $f_{A}$ 为吸引势, $f_{c}$ 为截断函数, $b_{i j}$ 为吸 引系数. 表 1 为本文模拟时用于描述 InGaAs中各类原 子间相互作用的 Tersoff势函数的参数 ${ }^{[21,22]}$.

\section{2 分子动力学模拟}

本文采用分子动力学模拟方法对理想 $I n G a A s$ 晶
体的熔化过程进行模拟. 首先将 8000 个原子(2000个 In原子、2000个 $\mathrm{Ga}$ 原子和4000个As原子)置于一个立 方体盒子中, 并在周期性边界条件下运行, 势函数为 tersoff势, 时间步长为 $1 \mathrm{fs}$. 其次将体系在 $200 \mathrm{~K}$, NVT系综下，等温运行 100000 步以获得平衡态的 InGaAs 晶体. 然后, 将InGaAs 晶体在 NPT系综下加 热到高于熔点的温度 $1700 \mathrm{~K}$, 整个熔化过程时长 30 $\mathrm{ns,}$ 升温速率为 $5 \times 10^{10} \mathrm{~K} / \mathrm{s}$, 升温速率的选取对模拟 结果影响不大, 所用模拟时长足以获得液态 $\mathrm{InGaAs}$, 这可以由系统的能量变化和径向分布函数确定. 然 后通过调整原子速度对系统逐级升温, 每次升温 10 $\mathrm{K}$, 每次升温后, 等温运行 200000 步, 并记录原子的 构型.

\section{2 结果与讨论}

\section{1 体熔点}

图 1 为理想 $I n G a A s$ 晶体熔化过程中比体积 (比体 积定义为 $S V=V / V_{0} ; V_{0}$ 是晶体的初始体积, $V$ 是某时刻 体系的体积)和原子平均能量随温度的变化关系. 从 图中可以看出, 随着温度的升高, 体系中原子的动能 和原子间距会增大, 体系的总能量和体积也相应增 大. 在体系熔化之前, In, Ga和As原子的动能不足以 摆脱晶格的束缚, 只能在平衡位置附近做较小的振 动, 因此体系的比体积和原子的平均能量随温度线 性增加. 当温度达到 $1280 \mathrm{~K}$ 附近时, 体系的体积比和 原子的平均能量发生了跃变, 表明体系发生了一级 相变.

\section{2 径向分布函数}

径向分布函数(radial distribution function, RDF) 是反映体系结构特征的一个统计参数, 它与 $X$ 射线衍

表 1 用于描述InGaAs中各类原子间相互作用的Tersoff势函数的参数 ${ }^{[21]}$

Table 1 Parameters of the Tersooff potentials used to describe the various types of inter-atomic interactions of InGaAs ${ }^{[21]}$

\begin{tabular}{lcllllclll}
\hline \multicolumn{1}{c}{ 参数 } & $A_{i j}(\mathrm{eV})$ & $B_{i j}(\mathrm{eV})$ & $\lambda_{i j}\left(\AA^{-1}\right)$ & $\mu_{i j}\left(\AA^{-1}\right)$ & \multicolumn{1}{c}{$c_{i}$} & $d_{i}$ & $h_{i}$ & $n_{i j}$ \\
\hline As-As & 1571.86 & 546.431 & 2.38413 & 1.72872 & 5.27313 & 0.75102 & 0.15292 & 0.60879 & 0.007488 \\
Ga-Ga & 993.88 & 136.123 & 2.520842 & 1.49082 & 0.076297 & 19.7964 & 7.14591 & 3.4729 & 0.23586 \\
In-In & 2975.54 & 360.61 & 2.6159 & 1.68117 & 0.084215 & 19.2626 & 7.39228 & 3.40223 & 2.10871 \\
Ga-As & 2579.46 & 317.21 & 2.82805 & 1.72303 & 1.2263 & 0.7904 & -0.51848 & 6.31747 & 0.35719 \\
In-As & 2246.55 & 417.665 & 2.53034 & 1.67123 & 1.30678 & 91.4432 & -0.56983 & 6.3319 & 0.38712 \\
In-Ga & 1214.917 & 177.22 & 2.5621 & 1.586 & 0.080256 & 195.295 & 7.2691 & 3.43739 & 0.70524 \\
\hline
\end{tabular}




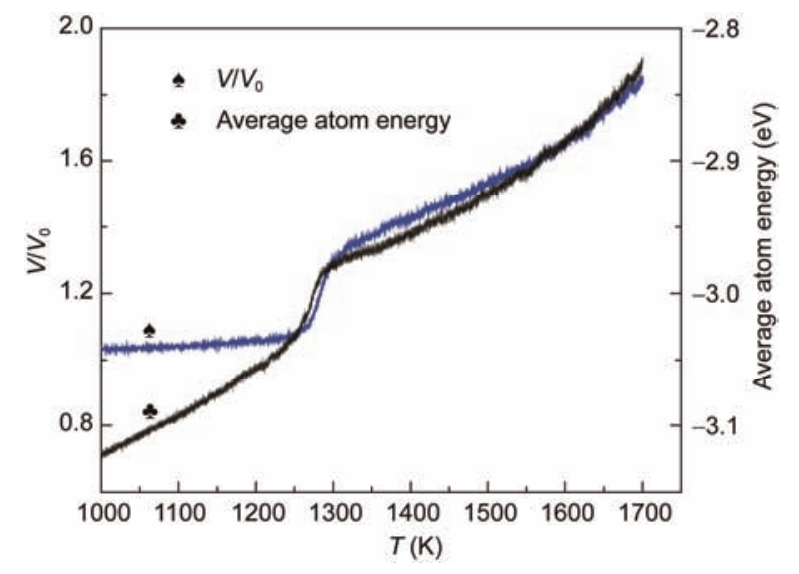

图 1 (网络版彩色)理想 InGaAs 晶体熔化过程中比体积和原子平均 能量随温度的变化关系

Figure 1 (Color online) Relations of the change of specific volume and the average energy of atoms with temperature during the melting process of ideal InGaAs crystal

射所得到的结构因子互为Fourier变换, 是理论模型 和实验结果比较的一个重要结构参数. 图2所示为理 想 InGaAs 晶体在其熔点附近的径向分布函数 RDF. 从图中可以看到, 在 $1200 \mathrm{~K}$ 前的 $g(r)$ 曲线有很多分 立的峰, 表明 $\mathrm{InGaAs}$ 晶体并没有熔化; 在 $1300 \mathrm{~K}$ 后 $g(r)$ 曲线主要有两个明显的峰, 而且第一峰后面的峰 值都很小, 与液态结构的 $g(r)$ 曲线一致, 表明此时理 想InGaAs晶体已经熔化. 在1200 1300 K时的径向分 布函数, 在 $100 \mathrm{~K}$ 温度间隔内, 理想 $\mathrm{InGaAs}$ 从晶体变 成了液体, 且 $g(r)$ 曲线发生较大的变化在 $1280 \mathrm{~K}$ 附近, 表明对于理想InGaAs 晶体, 熔化的一级相变过程发 生在1280 K附近. 此时, RDF的第一峰较低, 第二峰

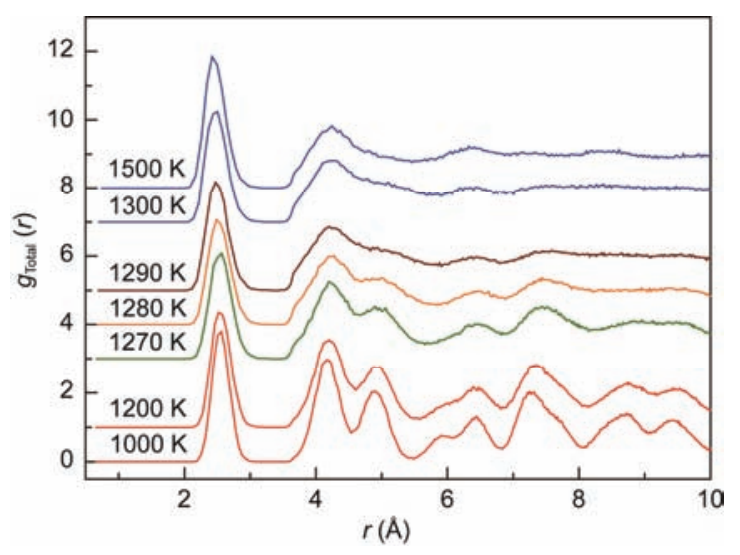

图 2 (网络版彩色) 理想InGaAs晶体在其熔点附近的双体分布函数

Figure 2 (Color online)The radial distribution functions near the melting point of ideal InGaAs crystal melting process
的分裂逐渐消失，接近液态结构.

\section{3 键角分布函数}

键角分布函数 (angular distribution function, ADF) 是以基本团簇为单元，分析团簇对称性的统计分析 方法, 可以反映出近邻原子与中心原子的位置关系. 图3给出了理想 $\mathrm{InGaAs}$ 晶体在熔点附近的键角分布 函数, 从图中可以看到, 在 $T<1300 \mathrm{~K}$ 时, $\mathrm{ADF}$ 的峰值 在 $109^{\circ}$ 附近, 表明此时 InGaAs 晶体以立方四配位结 构为主; 另外随着温度的升高, 峰值略有下降, 表明 立方四配位结构在减少. 在 $T>1200 \mathrm{~K}$ 时, ADF的峰值 在 $120^{\circ}$ 附近, 该键角对应于平面三配位结构, 表明在 1200 1300 K, 理想InGaAs晶体体系的结构发生很大 的变化. 从键角分布函数分析可以得到, 熔化的一级 相变过程会造成InGaAs体系结构发生较大的变化, 另外ADF的宽度较低温时更宽, 说明此时微观结构 是多种配位结构的结合, 仍旧保留了部分晶体拓扑 结构, 同时部分共价键断裂也促进了三配位结构的 增加.

\section{4 配位数}

配位数 (coordination number, $\mathrm{CN}$ )描写了粒子排 列的紧密程度, 可以从整体上反映最近邻原子的排 列情况, 是研究最近邻原子排列规律的一种统计方 法. 本文依据各温度下的RDF第一波谷位置选取该 温度截断距离, 用来判断成键关系进而统计配位数. 如图4所示, 理想InGaAs晶体在其熔点附近的二、三、 四配位数的变化, 从图可以看到, 在 $1200 \mathrm{~K}$ 时, 在

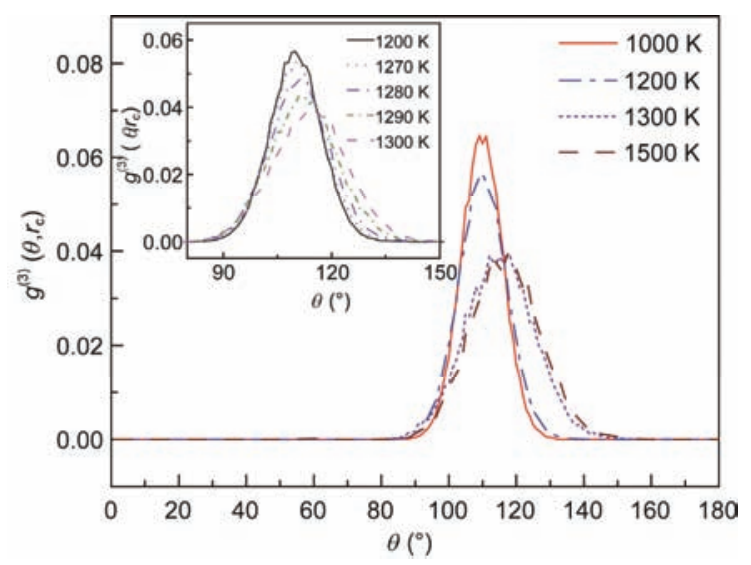

图 3 (网络版彩色)理想InGaAs晶体熔化过程中的键角分布函数

Figure 3 (Color online) The angular distribution functions in the melting process of ideal InGaAs crystal 


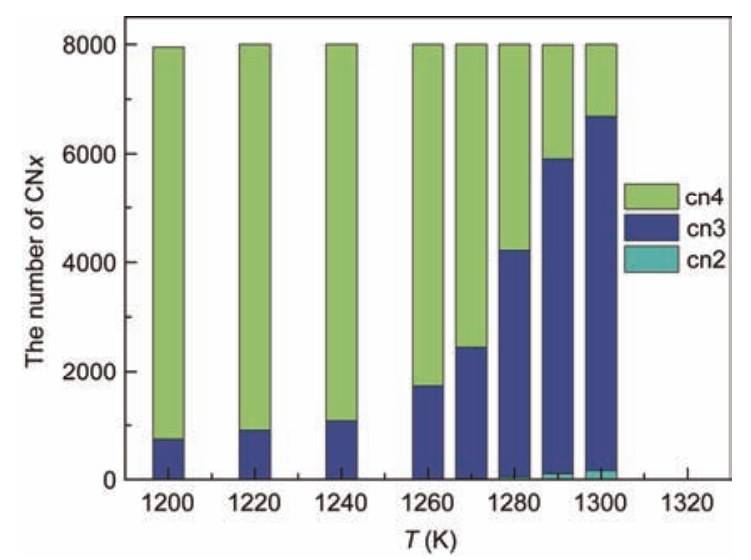

图 4 (网络版彩色)理想InGaAs晶体熔化过程中熔点附近的二、三、 四配位数的变化

Figure 4 (Color online) The changes of two, three or four coordination number in the melting point of ideal InGaAs crystal

InGaAs体系中, 四配位结构占有很大的比重; 随着 温度的升高, 当温度到达 $1280 \mathrm{~K}$ 附近时, 体系中的三 配位结构急剧增加, 四配位结构大幅度减少, 与前面 分析所得的理想InGaAs 晶体发生一级相变的温度点 相对应. 对于整个体系来说, 二配位结构原子所占的 比例很小. 因而熔化过程中, 体系的配位数主要由四 配位结构向三配位结构发生转变.

\section{5 微观结构分析}

(i ) 截面原子分布情况. 为了直观地显示理想 InGaAs 晶体熔化过程中微观结构的变化, 分别画出了 初始状态和熔点附近的InGaAs 系统局部(100)面的截 面图, 截面厚度为 3 个原子层, 如图5所示. 在 $200 \mathrm{~K}$ 时, 由于理想晶体的完美对称平移性, 其截面原子图排列 规整; 在 $1200 \mathrm{~K}$ 时, 随着温度的升高, 由于热力学效 应, 原子位置相对于其理想晶格位置有一定的偏离, 所以从截面图可以看到相对于 $200 \mathrm{~K}$ 时的原子截面图, $1200 \mathrm{~K}$ 时的截面图中出现了一些缺陷, 但整体的结构 并没有发生很大的变化; 随着温度的继续升高, 当温 度高于 $1280 \mathrm{~K}$ 时, 原子之间的势能不足以禁锢原子, 原子离开原来的位置, 原来的晶格排列遭到破坏, 排 列变得混乱. 结果表明: 理想InGaAs晶体发生熔化时, 其基本拓扑结构没有太大的变化, 但其原子的排列变 得混乱无章而使得微观结构发生较大的变化.

(ii) 局部原子分布情况. 为了更加细致地观察 理想InGaAs晶体熔化过程中微观结构的变化, 画出 了以 2168 号原子为中心的局部原子分布情况图, 如

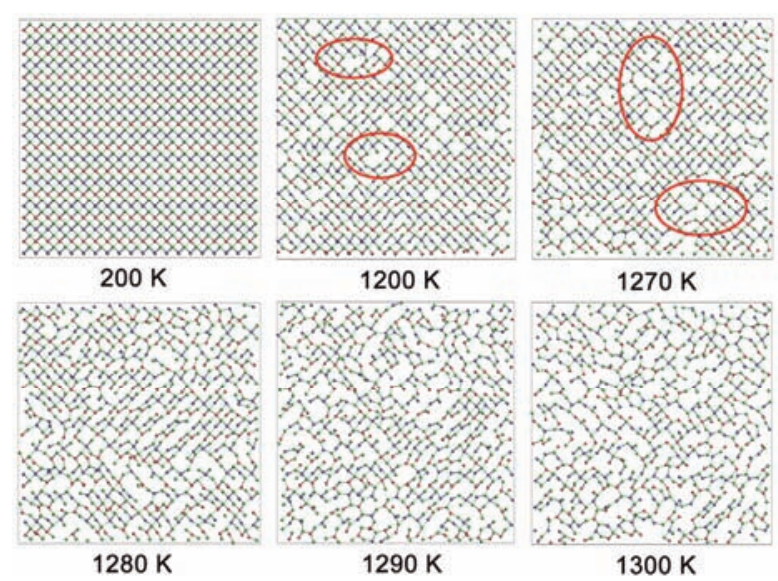

图 5 (网络版彩色)理想InGaAs晶体在初始状态和其熔点附近(100) 面的截面图

Figure 5 (Color online) The cross sections(100) in the initial state and the melting point of ideal InGaAs crystal

图6所示. 从图可以看到, 在 $200 \mathrm{~K}$ 时, 第一近邻和第 二近邻的原子分布均为标准的四配位结构, 原子间 的键角为 $109^{\circ} 28^{\prime}$; 随着温度的升高, 在 $1200 \mathrm{~K}$ 时, 第 一近邻和第二近邻的原子分布仍形成四配位结构, 只是原子间的键角略有变化, 这是因为随着温度的 升高, 原子在其附近发生振动, 所以键角发生变化, 但原子仍未脱离晶格的束缚. 在 $1280 \mathrm{~K}$ 之后, 第一近 邻和第二近邻的原子分布发生了变化, 在 $1280 \mathrm{~K}$ 时, 以 1363 和 1384 号原子为中心原子, 只有 3 个近邻原子; 在 1290 和 $1300 \mathrm{~K}$ 时, 各原子都只有 3 个近邻原子, 形 成了三配位结构, 原子间键角为 $116^{\circ}$ 左右. 结果表 明: 对于 $I n G a A s$ 体系, 当高于 $1280 \mathrm{~K}$ 时, 由于温度的 升高, 导致原子的运动加快, 动能增加, 原子之间共 价键发生断裂; 体系从四配位结构向三配位结构发 生转变, 结果与统计的配位数变化情况一致.

(iii) 钻石结构分析. 由于理想 InGaAs 晶体的 初始结构为完美的钻石结构, 为了清楚地观察其熔 化过程中的结构变化, 图7给出了理想 InGaAs在其熔 点附近钻石结构的变化情况. Cubic diamond (CD)表 示一个原子, 其所有的第一和第二近邻都位于立方 钻石的晶格位置; Cubic diamond (1st neighbor) (CD-1)表示一个原子作为第一近邻原子在立方钻石 晶格的位置, 但其第二近邻原子中至少有一个不在 立方钻石晶格的第二近邻位置上; Cubic diamond (2st neighbor)（CD-2)表示一个原子作为第二近邻原子在 立方钻石晶格的位置, 但它的近邻中至少有一个近 邻原子丢失或不在立方钻石晶格的位置上. 

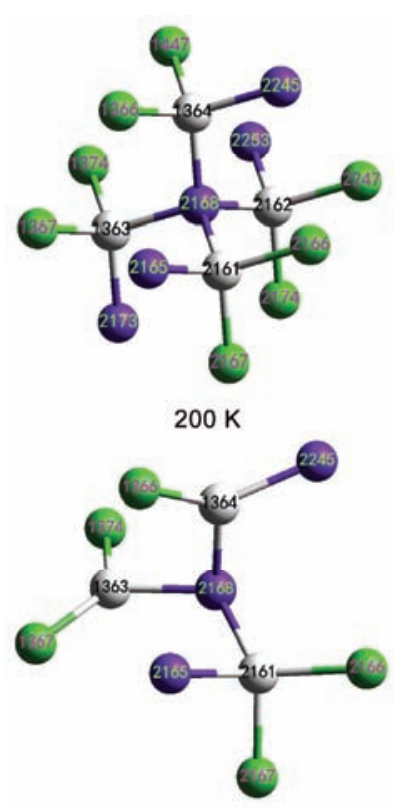

$1280 \mathrm{~K}$

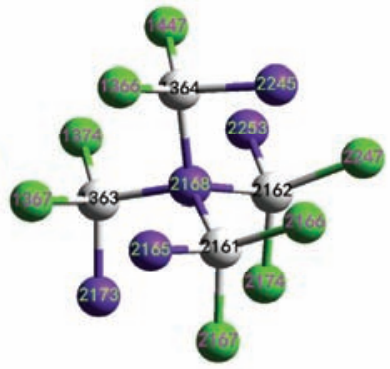

$1200 \mathrm{~K}$

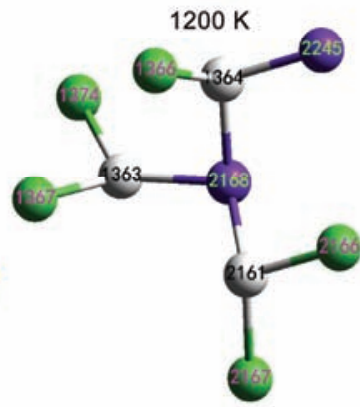

$1290 \mathrm{~K}$

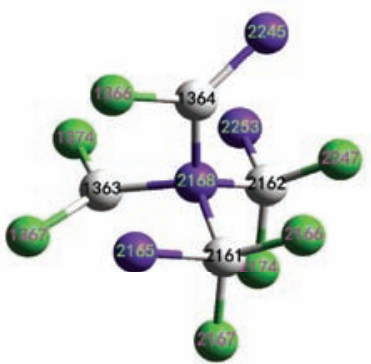

$1270 \mathrm{~K}$

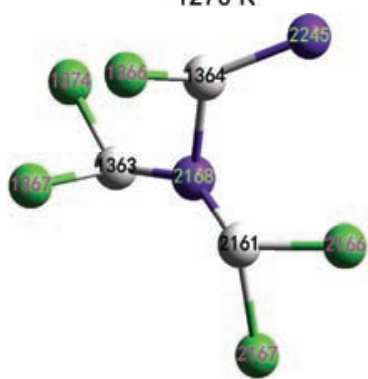

$1300 \mathrm{~K}$

图 6 (网络版彩色)理想InGaAs晶体在初始状态和其熔点附近局部原子分布情况

Figure 6 (Color online) The local atom distributions in the initial state and the melting point of ideal InGaAs crystal

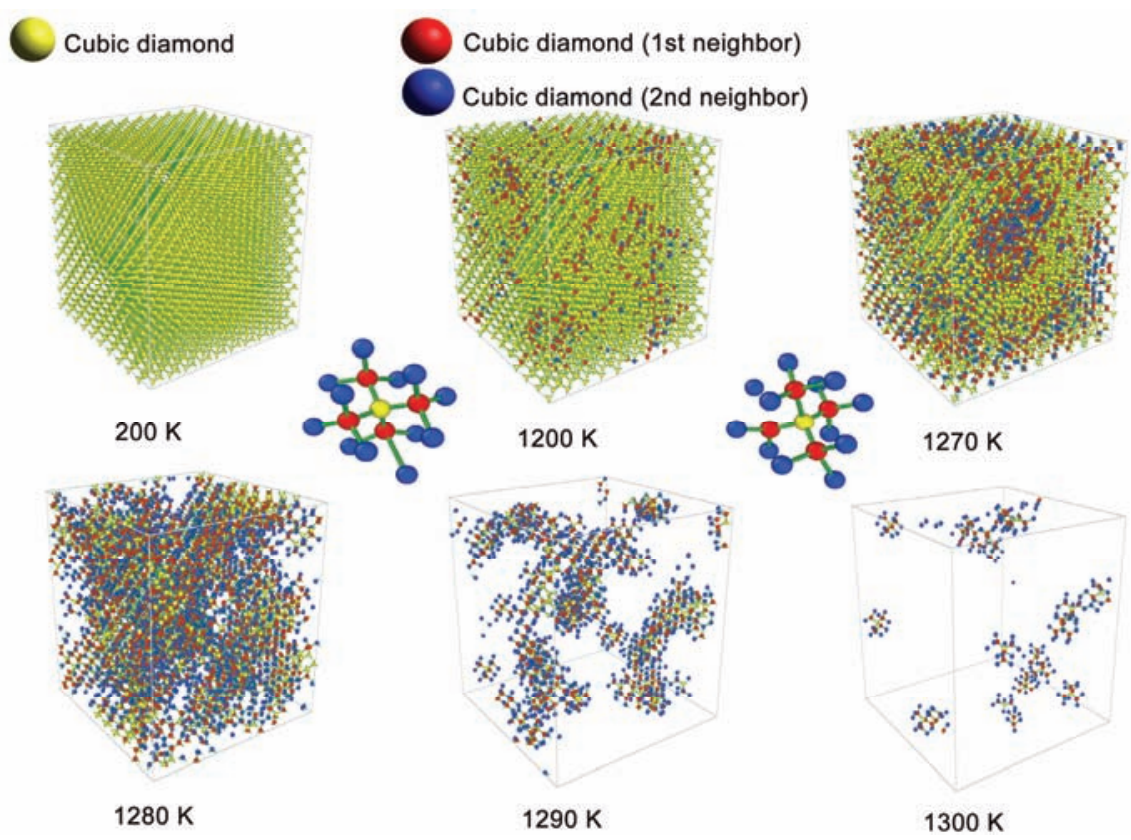

图 7 (网络版彩色)理想InGaAs晶体在初始状态和其熔点附近的钻石结构分析

Figure 7 (Color online) The analysis of the diamond structure in the initial state and the melting point of ideal InGaAs crystal

从图中可以看到, 在 $200 \mathrm{~K}$ 时, 理想 $\mathrm{InGaAs}$ 晶体 中全部都是 $\mathrm{CD}$ 类型原子. 随着温度的升高, 在 1200 $\mathrm{K}$ 时, 体系中出现了少量的 CD-1和 CD-2类型原子, 由于温度的升高, 原子在晶格附近振动, 导致某些原
子偏离了原来的晶格位置. 在 $1280 \mathrm{~K}$ 时，体系中 $\mathrm{CD}$ 类型原子急剧减少, 在 1290 和 $1300 \mathrm{~K}$ 时, 体系中 CD-1和CD-2类型原子也急剧减少, 表明InGaAs晶体 发生熔化时，体系的微观结构发生了很大的变化，原 
来的钻石结构几乎全部消失, 只保留了少量的晶体 团簇, 零散地分布在系统中, 此时整个体系中原子的 连接主要由三配位结构的互连接和三配位结构穿插 四配位结构的连接而构成拓扑结构.

\section{3 结论}

本文基于Tersoff提出的一个适合模拟结构和能 量相对复杂的共价键系统的 Tersoff势函数, 采用分 子动力学方法研究理想 $I n G a A s$ 晶体熔化过程中微观 结构的变化. 结果表明: 对于InGaAs体系, 熔化过程 中其微观结构发生了很大的变化, 其原子平均能量 和比体积、径向分布函数、键角分布函数、配位数和 原子截面图、局部原子分布以及钻石结构分析等, 在 一级相变时都显示出了很明显的变化. 对于熔化过 程, 从原子运动的角度看, 由于温度的升高, 导致原
子运动加快, 动能增加, 当原子动能增加到一定程度 的时候, 原子之间的势能就不足以禁锢原子, 原子就 会离开原来的平衡位置, 原来的晶格排列将遭到破 坏, 原子的位置排列变得混乱, 就从固态转变成了液 态; 从能量角度看, 由于温度的升高, 原子与原子间 的共价键发生断裂和重组, 形成新的稳态结构. 在 $\mathrm{InGaAs}$ 晶体熔化过程中，在 $1280 \mathrm{~K}$ 时原子间共价键 发生断裂, 体系从四配位结构转变为三配位结构, 通 过少量的四配位结构, 形成占主导地位的三配位结 构的互相连接, 并且以三配位结构穿插四配位结构 的连接形成拓扑无序的液态结构. 对于理想 InGaAs 晶体熔化过程的研究, 通过对微观结构的分析, 可以 从原子的角度更清楚地看到在发生一级相变时结构 的变化. 该结果对于实验上探究多组元化合物的熔 点也有一定参考价值.

\section{参考文献}

1 Lindemann F. The calculation of molecular natural frequencies. F Phys Z, 1910, 11: 609-612

2 Born M. Thermodynamics of crystals and melting. J Chem Phys, 1939, 7: 591-603

3 Jin Z H, Gumbsch P, Lu K, et al. Melting mechanisms at the limit of superheating. Phys Rev Lett, 2001, 87: 055703

4 Lutsko J F, Wolf D, Phillpot S R, et al. Molecular-dynamics study of lattice-defect-nucleated melting in metals using an embedded-atom-method potential. Phys Rev B, 1989, 40: 2841-2855

5 Berry R S, Jellinek J, Natanson G. Melting of clusters and melting. Phys Rev A, 1984, 30: 919-931

6 Honeycutt J D, Andersen H C. Molecular dynamics study of melting and freezing of small Lennard-Jones clusters. J Phys Chem, 1987, 91: 4950-4963

7 Kim S G, Tománek D. Melting the fullerenes: A molecular dynamics study. Phys Rev Lett, 1994, 72: 2418-2421

8 Petkov V, Billinge S J L. Local structure of random $\operatorname{In}_{x} \mathrm{Ga}_{1-x}$ As alloys by full-profile fitting of atomic pair distribution functions. Phys Rev B-Condens Matter, 2001, 305: 83-89

9 Rathi P, Sikder S, Adhikari J. Structural characterization of III-V zinc blende compound semiconductors using Monte Carlo simulations. Comput Mater Sci, 2012, 65: 122-126

10 Suzuki T, Nakajima K, Kusunoki T, et al. Multi-component zone melting growth of ternary InGaAs bulk crystal. J Electron Mater, 1996, 25: $357-361$

11 Titantah J T, Lamoen D, Schowalter M, et al. Bond length variation in $\mathrm{In}_{x} \mathrm{Ga}_{1-x}$ As crystals from the Tersoff potential. J Appl phys, 2007, 101: 123508

12 Adhikari J. Molecular simulation study of the structural properties in $\operatorname{In}_{x} \mathrm{Ga}_{1-x}$ As alloys: Comparison between valence force field and Tersoff potential models. Comput Mater Sci, 2008, 43: 616-622

13 Dash J G. History of the search for continuous melting. Rev Mod Phys, 1999, 71: 1737-1743

14 Tersoff J. Modeling solid-state chemistry: Inter-atomic potentials for multi-component systems. Phys Rev B, 1989, 39: 5566-5568

15 Tersoff J. Empirical inter-atomic potential for silicon with improved elastic properties. Phys Rev B, 1988, 38: 9902-9905

16 Chen Z L, Xu W R, Tang L D. Molecular Simulation Theory and Practice (in Chinese). Beijing: Chemical Industry Press, $2007.2-3$ [陈 正隆, 徐为人, 汤立达. 分子模拟的理论与实践. 北京: 化学工业出版社, 2007. 2-3]

17 Mountain R D, Basu P K. Molecular dynamics study of homogeneous nucleation for liquid rubidium. J Chem Phys, 1983, 78: 7318-7322

18 Li D H, Moore R A, Wang S. A computer and analytic study of the metallic liquid-glass transition. II. Structure and mean square displacements. J Chem Phys, 1988, 89: 4309-4312

19 Yan W J, Gao T H, Guo X T, et al. Melting kinetics of bulk SiC using molecular dynamics simulation. Sci China Phys Mech Astron, 2013, 56: 1699-1704

20 Volz S G, Chen G. Molecular-dynamics simulation of thermal conductivity of silicon crystals. Phys Rev B, 2000, 61: 2651-2656

21 Nordlund K, Nord J, Frantz J, et al. Strain-induced Kirkendall mixing at semiconductor interfaces. Comput Mater Sci, 2000, 18: 283-294

22 Smith R. A semi-empirical many-body inter-atomic potential for modeling dynamical processes in gallium arsenide. Phys Res Sect B, 1992, 67: 335-339 


\title{
Evolution mechanism of the topological structure during solid-liquid phase transition of InGaAs crystal
}

\author{
HE Fan, ZHANG JinMin*, GAO TingHong, TIAN ZeAn, LIANG YongChao, GUO XiaoTian, \\ LU ShunShun, CHEN Qing \& XIE Quan \\ Institute of New Optoelectronic Materials and Technology, College of Electronic Information, Guizhou University, Guiyang 550025, China \\ * Corresponding author, E-mail: jmzhang@gzu.edu.cn
}

Melting refers to the phase transition from solid to liquid, which is a common physical phenomenon in nature. It is also a phase transformation process that the materials such as metals and semiconductors need to undergo in the process. It is closely related to the preparation and performance of materials. At present, it is difficult to trace the microstructure of the melting process, and computer simulation can get a lot of microstructure information of the melting process, which can well explain how the orderly arrangement of crystals becomes random liquid phase structure in the melting process. For the ternary semiconductor alloy $\operatorname{In}_{x} \mathrm{Ga}_{1-x} \mathrm{As}$, it has important application value in microelectronics and optoelectronic devices, because it can adjust its electrical parameters and optical band gap in a wide range composition. So the research of alloy structure has been paid more and more attentions for the ternary semiconductor. It is generally known that the macroscopic properties of the materials are mainly determined by their microstructures. However, most studies on the melting process are based on the dynamics, but the mechanism of the evolution of the microstructure during the melting process is lacking. Therefore, it is of great significance to study the evolution of microstructures during the melting process of InGaAs crystals in the development of novel optoelectronic materials and devices.

At present, it is still difficult in the experiment to obtain the structural details of InGaAs system during the melting process. Molecular dynamics simulation is an efficient tool especially for such process. In this paper, the melting process of the ideal InGaAs crystal is simulated by using the molecular dynamics method, and the Tersoff potential function of the $\mathrm{In}_{x} \mathrm{Ga}_{1-x} \mathrm{As}$ covalent bond system, which has been proved to be suitable for the simulation of complex structures. The structural evolution of the solid-liquid phase transition process was analyzed by using the radial distribution function, angular distribution function, coordination numbers and 3D visualization. From the results of our simulation, we find that the microstructures of the InGaAs phase change greatly during the solid-liquid phase transition, especially in the first-order phase transition. It shows significant variations in the average atomic energy and specific volume, the radial distribution function, angular distribution functions, coordination numbers and atomic cross-sections, local atomic distributions, and diamond structure analysis. In the melting process, covalent bonds the InGaAs atoms are broken, and the system changes from the four coordinated structure into the three coordinated structure. For the dominant three coordinated structure and a small amount of four coordinated structures, the three coordinated structure is connected with the three coordinated structure, and the three coordinated structure interpenetrated the four coordinated structure to form a disordered topological structure.

molecular dynamics simulation, InGaAs crystal, solid-liquid phase transition, topological structure doi: 10.1360/N972016-00742 